\title{
Dissolved Heavy Metals Distribution and Risk Assessment in the Le'an River Subjected to Violent Mining Activities
}

\author{
Yinghui Jiang ${ }^{1}$, Huanqing Xie ${ }^{2}$, Hua Zhang ${ }^{1 *}$, Zhenglei Xie ${ }^{1 *}$, Yun Cao ${ }^{1}$ \\ ${ }^{1}$ Key Laboratory of Education Ministry for Poyang Lake Wetland and Watershed Research, College of Geography \\ and the Environment, Jiangxi Normal University, Nanchang 330022, P.R. China \\ ${ }^{2}$ School of Hydraulic and Ecological Engineering, Nanchang Institute of Technology, \\ Nanchang 330099, P.R. China
}

Received: 30 June 2017

Accepted: 15 September 2017

\begin{abstract}
Surface water samples were collected from 24 sampling sites throughout the Le'an River during wet and dry seasons. The concentrations of dissolved heavy metals were determined by inductively coupled plasma-mass spectrometry (ICP-MS). The sources of dissolved heavy metals in the Le'an River were investigated based on the seasonal and spatial variations. The results demonstrated that significant seasonality of dissolved heavy metals concentrations were found in the Le'an River, and high concentrations in dry season due to the precipitation dilution effect. Spatially, higher concentrations of selected dissolved heavy metals were distributed in the mining area, which was significantly influenced by mining activities. It was found that sites within the mining area suffered from serious pollution based on the calculated HPI and MPI. According to human health risk assessment, it was indicated that As, Co, and $\mathrm{Cd}$ were the major contributors to exposure to local inhabitants. The exposure risks of the adults were less sensitive compared to the children, and oral ingestion was the primary exposure pathway. Multivariate statistical analyses revealed that different groups of heavy metals were characteristics of the disparate source associated with mineral exploration, urban and agricultural activities, and geogenic origins. Hierarchical agglomerative CA grouped all the sampling sites into three clusters based on the data set of exposure risk to human health and aquatic life. In cluster 2, concentrations of $\mathrm{Cd}$ and As were higher than drinking water quality of WHO and Chinese standards.
\end{abstract}

Keywords: dissolved heavy metals, health risk assessment, source identification, Le'an River

\section{Introduction}

Mining exploration and processing of metal ores provide economic benefits of production, and also bring se-

*e-mail: zhalxx@163.com,xz12121@163.com rious contamination to the environment [1]. Heavy metals contamination in the environment being influenced by mining exploration has caused widespread concern [2-5]. In China, violent mining activities have resulted in heavy metal pollution in numerous rivers [6]. The accumulation of dissolved heavy metals in river water is hazardous to both aquatic ecosystems 
and human health when their values are higher than the corresponding threshold [7-9]. Therefore, risk assessment of human health and identification of potential sources are necessary and important for the protection of water resources and river aquatic ecosystems [10].

Heavy metals input to river ecosystems from mining areas mainly comes in the form of mine wastewater discharge, atmospheric deposition, surface and subsurface runoff, and rock chemical weathering [11-13]. River surface water was particularly easily contaminated by heavy metals due to open environment for disposal of various contaminants [14]. As the numerous sources, non-degradability, bio-accumulation, and persistence, heavy metals enrichment in a river ecosystem could significantly threaten the aquatic life and human population [15-16]. Heavy metals caused significant concern due to their direct effect on aquatic environment safety [17-18], which greatly contributed various diseases and high risks to human health owing to their accumulation and biomagnification in the human body [14]. Although some heavy metals such as $\mathrm{Fe}, \mathrm{Cu}, \mathrm{Zn}$, and Ni were essential for animal and plant metabolism, they were also potential for affecting the neurological system, kidney function, the ossification process, and various other high-level organs [19]. Other metals such as $\mathrm{Cd}, \mathrm{Cr}$, and $\mathrm{Pb}$ were highly related with bladder cancer, neurotoxicity, and dysfunction of the hematopoietic system [20-21]. It had also been observed that chro-nic exposure to low doses of cancer-causing heavy metals might cause many types of cancer [22]. Increased risk of lung cancer death was inevitable from occupational exposure to dusts and mists containing hexavalent chromium [23]. These included dermal, respiratory, cardiovascular, gastrointestinal, haematological, hepatic, renal, neurological, developmental, reproductive, immunological, genotoxic, mutagenetic, and carcinogenic effects [22]. It is crucial to assess the health risks posed on human beings by ingestion of toxic metals through various pathways. Moreover, non-carcinogenic health risks would be evaluated to explore the adverse health effects on inhabitants due to ingestion of and dermal contact with water.

The Le'an River is not only a significant irrigation source for adjacent agriculture, but also is an important source of drinking water [24]. Their aqueous ecosystems were significantly contaminated by heavy metals discharged from a copper mine (the largest open-cast copper mine in Asia), a $\mathrm{Pb}-\mathrm{Zn}$ mine, and other mines [25-27]. Heavy metal concentrations in soil and sediment of the Le'an River basin were significantly higher than their corresponding background values. For instance, mean concentrations of $\mathrm{Cd}, \mathrm{Pb}, \mathrm{Cu}$, and $\mathrm{Zn}$ in sediment were $4.713,100.94,391.50$, and $273.29 \mathrm{mg} / \mathrm{kg}$, respectively, and concentration of $\mathrm{Cu}$ in agricultural soil was $64.8 \mathrm{mg} / \mathrm{kg}$, which greatly surpass their background values $(0.095 \mathrm{mg} / \mathrm{kg}$ for $\mathrm{Cd}, 30.4 \mathrm{mg} / \mathrm{kg}$ for $\mathrm{Pb}, 22.2 \mathrm{mg} / \mathrm{kg}$ for $\mathrm{Cu}$, and $81.1 \mathrm{mg} / \mathrm{kg}$ for $\mathrm{Zn}$ ) [28-29]. High enrichment of metals caused great effect on the environment of the river basin, and much research has studied the distribution and subsequent ecological risk of metals in some medium (soil and sediment) [24, 29-30]. However, the spatial-temporal distribution and potential sources and human health risk of the dissolved heavy metals were still little known. It is necessary and important for managing the metal pollution in river and protecting aqueous ecosystems. Moreover, the Le'an is a significant tributary of Poyang Lake - the largest freshwater lake in China. The results from these studies are also significant for the aqueous ecosystem and human health of the lake.

The objectives of this study were:

1) Analyze and evaluate the spatial and temporal variation and pollution levels of dissolved heavy metals in the Le'an River.

2) Identify possible sources and explore the factors that control the availability of dissolved heavy metals.

3) Assess the human health risk subjected to dissolved heavy metals with two population groups.

\section{Materials and Methods}

\section{Study Area}

The Le'an is located in northeastern Jiangxi Province, China (Fig. 1). It starts from Huaiyu Mountain and runs $279 \mathrm{~km}$ from east to west. The river's basin covers $8,989 \mathrm{~km}^{2}$ and flows through Wuyuan, Dexing, Leping, and Poyang counties before flowing into Poyang Lake. Its mean annual runoff is $99.367 \times 10^{8} \mathrm{~m}^{3}$ and average annual precipitation is $1,687-1,870 \mathrm{~mm}$, most of which is concentrated in summer. Dexing is the famous nonferrous metal mineral development zone in China, and Dexing copper mine is the largest open-cast mine in Asia [31], and $\mathrm{Pb}-\mathrm{Zn}$ ore is located downstream of Jishui River (the most important tributary of the Le'an and adjacent to the city of Dexing). Some small-scale mineral development zone is distributed in other areas of the river basin. The Dawu River is an important sewage outfall of Dexing Copper Mine. Most agriculture is distributed downstream of the Le'an River (after S14; Fig. 1).

\section{Sample Collection}

Four sampling campaigns throughout the Le'an River in May, August, October, and December 2016 were conducted. Surface water samples were collected in 24 sites except May (21 sites) along mainstream, and an important tributary (Jishui River) of the Le'an. Thus, a total of 93 water samples were collected at a depth of approximately $10 \mathrm{~cm}$ (Fig. 1). In each site, three replicates $(250 \mathrm{~mL})$ were taken about $100 \mathrm{~m}$ apart and collected at a depth of approximately $10 \mathrm{~cm}$ below the surface water of the river by using previously acid-washed (15\% (v/v) $\mathrm{HNO}_{3}$ for $24 \mathrm{~h}$ ) high-density polyethylene (HDPE) containers, which were subsequently well mixed. These mixed samples were immediately filtered through a prewashed $0.45-\mu \mathrm{m}$ nitrocellulose filter, and the initial filtration was thrown away to clean the container. 


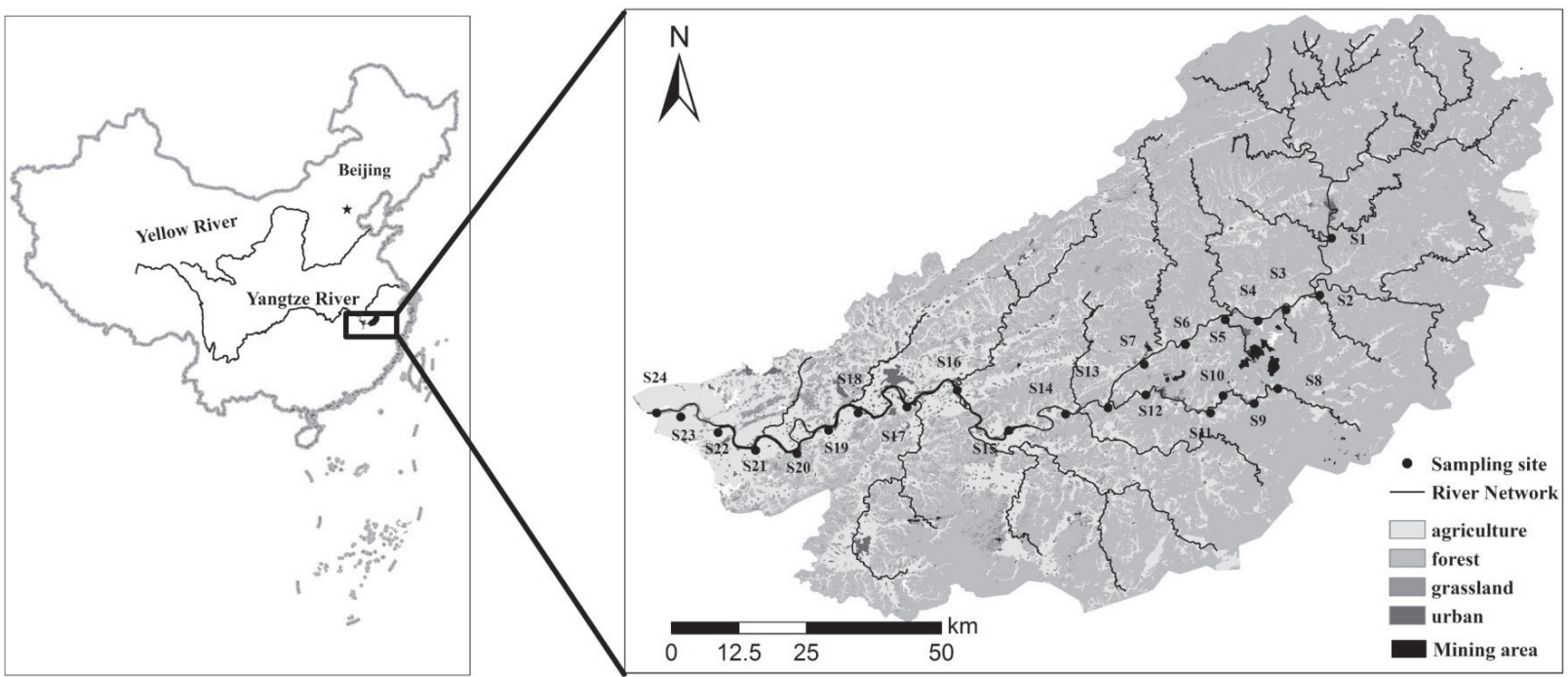

Fig. 1. Map of the study area with sampling locations.

The remaining portion was stored and acidified to $\mathrm{pH}<2$ with suprapure nitric acid in situ later. After that, the samples were kept in an ice box and then transported to the laboratory and stored in a refrigerator before analysis.

\section{Determining Heavy Metals}

To explore the dissolved heavy metals concentration in surface water and human health risk in the river water of the Le'an River Basin, the concentrations of vanadium $(\mathrm{V})$, chromium $(\mathrm{Cr})$, cobalt $(\mathrm{Co})$, nickel $(\mathrm{Ni})$, copper $(\mathrm{Cu})$, zinc $(\mathrm{Zn})$, cadmium $(\mathrm{Cd})$, barium $(\mathrm{Ba})$, lead $(\mathrm{Pb})$, iron $(\mathrm{Fe})$, and arsenic (As) were determined by inductively coupled plasma-mass spectrometry (ICP-MS, Thermo Fisher $\mathrm{X}$ series). The limit of detection was $0.047 \mu \mathrm{g} / \mathrm{L}$ for $\mathrm{V}$, $0.026 \mu \mathrm{g} / \mathrm{L}$ for $\mathrm{Cr}, 0.006 \mu \mathrm{g} / \mathrm{L}$ for $\mathrm{Co}, 0.054 \mu \mathrm{g} / \mathrm{L}$ for $\mathrm{Ni}, 0.055 \mu \mathrm{g} / \mathrm{L}$ for $\mathrm{Cu}, 0.04 \mu \mathrm{g} / \mathrm{L}$ for $\mathrm{Zn}, 0.003 \mu \mathrm{g} / \mathrm{L}$ for $\mathrm{Cd}, 0.012 \mu \mathrm{g} / \mathrm{L}$ for $\mathrm{Ba}, 0.045 \mu \mathrm{g} / \mathrm{L}$ for $\mathrm{Pb}, 0.309 \mu \mathrm{g} / \mathrm{L}$ for As, and $2.612 \mu \mathrm{g} / \mathrm{L}$ for Fe. Recovery rates of trace elements spiked in water fell into the range from 89 to $110 \%$. In order to assess the absence of any contamination occurring from reagents and materials, whole procedure blank tests were performed on double-deionized water (Milli-Q System, Millipore) to keep matrix interference (blank) $<2 \%$. Triplicates of sample analysis yielded a relative standard deviation (RSD) of $<5 \%$. Otherwise, the determinations were done again until all data reach the standard.

\section{Heavy Metal Pollution Index}

Heavy metal pollution index (HPI) was based on the weighted arithmetic mean calculation of selected parameters to evaluate the critical level (100) of water quality The HPI was calculated as the following expressions according to Horton (1965) [32]:

$$
\mathrm{HPI}=\frac{\sum_{i=1}^{n} W_{i} Q_{i}}{\sum_{i=1}^{n} W_{i}}
$$

...where $\mathrm{W}_{i}$ is the unit weighting factors of selected parameters and $\mathrm{Q}_{i}$ is sub-index of the $i$ th parameters. $\mathrm{Q}_{i}$ was obtained through the following equation, which is specified below:

$$
\mathrm{Q}_{\mathrm{i}}=\sum_{\mathrm{i}=1}^{\mathrm{n}} \frac{\left\{\mathrm{M}_{\mathrm{i}}(-) \mathrm{I}_{\mathrm{i}}\right\}}{\left(\mathrm{S}_{\mathrm{i}}-\mathrm{I}_{\mathrm{i}}\right)} \times 100
$$

...where $\mathrm{M}_{i}$ is the monitored value of heavy metal of $i$ th parameter, $\mathrm{I}_{i}$ is the ideal/baseline value of the $i$ th parameter, and $\mathrm{S}_{i}$ is the standard value of the $i$ th parameter. The sign (-) only demonstrates numerical difference, ignoring the algebraic sense.

The HPI was always applied for assessing water quality served as drinking [33]. In this study, the HPI was applied for evaluating the water quality served as habitat for aquatic life. Therefore, the weighted $\left(\mathrm{W}_{i}\right)$ was calculated as the inverse of $\mathrm{S}_{i}$, namely criterion maximum concentration (CMC; for protection of aquatic life) and $\mathrm{I}_{i}$-used criterion continuous concentration (CCC) as ideal value of the selected metal. The specific parameters of HPI in this study are listed in Table S1. The calculated HPI only relates to $\mathrm{Cr}, \mathrm{Ni}, \mathrm{Cu}, \mathrm{Cd}$, and $\mathrm{Pb}$ due to lack of the corresponding recommended standard for other investigated metals. The critical pollution level of the HPI value is similarly set at 100 , as given by Prasad and Bose [34].

\section{Metal Pollution Index}

Metal pollution index (MPI) depicts the composite effects of all selected metals on water quality [35]. The MPI is calculated as the sum of the ratio between the concentrations of selected heavy metals and their corresponding maximum allowable concentrations 
(MAC). The drinking water standards of China [36] are applied as MAC for the heavy metals. The MPI was calculated as the following equation:

$$
\mathrm{MPI}=\sum_{\mathrm{i}=1}^{\mathrm{n}} \frac{\mathrm{c}_{\mathrm{i}}}{(\mathrm{MAC})_{\mathrm{i}}}
$$

...where $c_{i}$ represents concentrations of the 'ith' metal and MAC represents maximum allowable concentrations.

Water quality based on MPI is categorized into six different classes: MPI of $<0.3$ represents very pure (Class I), 0.3-1.0 poor (Class II), 1.0-2.0 slightly affected (Class III), 2.0-4.0 moderately affected (Class IV), 4.0-6.0 strongly affected (Class V), and a MPI of $>6.0$ represents seriously affected (Class VI) [37].

\section{Assessing Human Health Risk}

Health risk of local people was evaluated by risk guidelines of USEPA [38] due to lack of standard for acceptable maximum carcinogenic and non-carcinogenic levels in China, which was proved successful and adopted worldwide. Dissolved heavy metal in water enters into the human body through direct ingestion and dermal absorption. The chronic daily intake of direct ingestion $\left(\mathrm{CDI}_{\text {ingestion }}\right)$ and dermal absorption $\left(\mathrm{CDI}_{\text {dermal }}\right)$ for dissolved heavy metals were calculated by the following expressions:

$$
\begin{gathered}
\mathrm{CDI}_{\text {ing }}=\frac{\mathrm{C}_{\mathrm{w}} \times \mathrm{IR} \times \mathrm{EF} \times \mathrm{ED}}{\mathrm{BW} \times \mathrm{AT}} \\
\mathrm{CDI}_{\text {dermal }}=\frac{\mathrm{C}_{\mathrm{w}} \times \mathrm{SA} \times \mathrm{K}_{\mathrm{p}} \times \mathrm{ET} \times \mathrm{EF} \times \mathrm{ED} \times \mathrm{CF}}{\mathrm{BW} \times \mathrm{AT}}
\end{gathered}
$$

The values, descriptions, and sources of parameters in the previous expressions are presented in Table S2.

The hazard quotient (HQ) is used to evaluate noncarcinogenic health risk, which equals the quotient between CDI and the oral reference dose (RfD) using the following equation as prescribed by the USEPA [38]:

$$
\mathrm{HQ}=\frac{\mathrm{CDI}}{\mathrm{RfD}}
$$

...where RfD is the corresponding reference of average intake of each exposure pathway which gains from the USEPA [38] database. The values of RfD for ingestion and dermal exposure in this study are presented in Table 2. The RfD values of each dissolved heavy metal are used to determine HQ value for children and adults. The hazard index (HI) values of local people equal total HQ value of each exposure pathway and are constituted by children and adults. The value of HI is calculated by the following expression according to the USEPA [39];

$$
\mathrm{HI}=\sum \mathrm{HQ}
$$

Values of HQ and HI less than one $(<1)$ are considered as no risk for local human health, while the values greater than one $(>1)$ are regarded as high risk of the toxicants and long-term health hazard effects.

\section{GIS and Statistical Analysis}

The distributions of each dissolved heavy metal in the Le'an River were presented by using ArcGIS software. One-way analysis of variance (ANOVA) was applied to compare the seasonal difference. The overlying factors control the interaction and the relationship between the different variables were identified by principal component analysis (PCA). Factor analysis (FA) was used to maximally reduce the variables and extracted the factors with eigenvalues greater than 1. Moreover, Kaiser-Meyer-Olkin (KMO) and Bartlett's sphericity tests were performed to test the suitability of the raw data for PCA/FA. Reduction of variables is accepted when the KMO values are $>0.5$ and $\mathrm{p}<0.05$ [40]. The interrelationship among the selected variables was tested by Pearson's coefficient analysis with statistical significance set a priori at $\mathrm{p}<0.05$. Cluster analysis (CA) was always used to classify the similar variables and cases. In this study, hierarchical agglomerative CA was applied to the normalized data set to test sites' similarity with the squared Euclidean distance with the betweengroup linkage method.

\section{Results and Discussion}

Concentrations of River Surface Water-dissolved Heavy Metals and their Spatial Distribution

The descriptive statistics of dissolved heavy metals and their distributions in the Le'an are presented in Table 1 and Fig. 2, respectively. The order of mean dissolved heavy metals concentrations in May and August (wet season) were: Fe $(621.87 \mu \mathrm{g} / \mathrm{L})>\mathrm{Ba}(24.38 \mu \mathrm{g} / \mathrm{L})>\mathrm{Zn}$

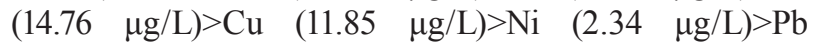

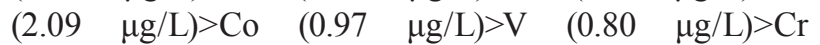
$(0.58 \mu \mathrm{g} / \mathrm{L})>\mathrm{Cd}(0.41 \mu \mathrm{g} / \mathrm{L})$ and $\mathrm{Fe}(368.18 \mu \mathrm{g} / \mathrm{L})>\mathrm{Ba}$ $(46.63 \mu \mathrm{g} / \mathrm{L})>\mathrm{Zn} \quad(17.35 \mu \mathrm{g} / \mathrm{L})>\mathrm{Cu} \quad(8.69 \mu \mathrm{g} / \mathrm{L})>\mathrm{Ni}$

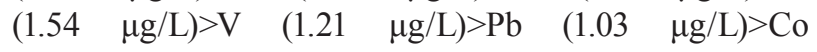
$(0.63 \mu \mathrm{g} / \mathrm{L})>\mathrm{Cr}(0.30 \mu \mathrm{g} / \mathrm{L})>\mathrm{Cd}(0.27 \mu \mathrm{g} / \mathrm{L})$. The order of mean dissolved heavy metals concentrations in October and December (dry season) were: Fe $(404.59 \mu \mathrm{g} / \mathrm{L})>\mathrm{Zn}$ $(90.36 \mu \mathrm{g} / \mathrm{L})>\mathrm{Ba} \quad(54.69 \mu \mathrm{g} / \mathrm{L})>\mathrm{Cu} \quad(11.93 \mu \mathrm{g} / \mathrm{L})>\mathrm{As}$ $\left(\begin{array}{lllll}3.67 \mu \mathrm{g} / \mathrm{L}) & >\mathrm{Ni} & (2.09 \mu \mathrm{g} / \mathrm{L})>\mathrm{Pb} & (2.02 \mu \mathrm{g} / \mathrm{L})>\mathrm{V}\end{array}\right.$

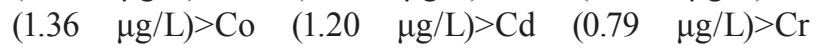
$(0.34 \mu \mathrm{g} / \mathrm{L})$ and $\mathrm{Fe}(474.26 \mu \mathrm{g} / \mathrm{L})>\mathrm{Zn}(73.58 \mu \mathrm{g} / \mathrm{L})>\mathrm{Ba}$ $\left(\begin{array}{llll}55.26 & \mu \mathrm{g} / \mathrm{L})>\mathrm{Cu} \quad(11.41 \mu \mathrm{g} / \mathrm{L})>\mathrm{Pb} \quad(4.94 \mu \mathrm{g} / \mathrm{L})>\mathrm{As}\end{array}\right.$ $(3.14 \mu \mathrm{g} / \mathrm{L})>\mathrm{Cd} \quad(2.94 \mu \mathrm{g} / \mathrm{L})>\mathrm{Ni} \quad(2.91 \mu \mathrm{g} / \mathrm{L})>\mathrm{Co}$ $(1.72 \mu \mathrm{g} / \mathrm{L})>\mathrm{V}(1.35 \mu \mathrm{g} / \mathrm{L})>\mathrm{Cr}(0.65 \mu \mathrm{g} / \mathrm{L})$. Based on the spatial distributions of heavy metal concentrations (Fig. 3), Cu, Zn, Cd, Ba, and As had similar characteristics. The lowest levels of these metals $(2.99 \mu \mathrm{g} / \mathrm{L}, 4.95 \mu \mathrm{g} / \mathrm{L}$, $0.03 \mu \mathrm{g} / \mathrm{L}, 15.95 \mu \mathrm{g} / \mathrm{L}$, and $0.83 \mu \mathrm{g} / \mathrm{L}$ for $\mathrm{Cu}, \mathrm{Zn}, \mathrm{Cd}$, 
Table 1. Statistical characteristic of heavy metal concentrations in surface water of the Le'an River $(\mu \mathrm{g} / \mathrm{L})$.

\begin{tabular}{|c|c|c|c|c|c|c|c|c|c|c|c|}
\hline May & V & $\mathrm{Cr}$ & Co & $\mathrm{Ni}$ & $\mathrm{Cu}$ & $\mathrm{Zn}$ & $\mathrm{Cd}$ & $\mathrm{Ba}$ & $\mathrm{Pb}$ & $\mathrm{Fe}$ & \\
\hline mean & $0.80 \mathrm{a}$ & $0.58 \mathrm{a}$ & $0.97 \mathrm{ab}$ & $2.34 \mathrm{ab}$ & $11.85 \mathrm{a}$ & $14.76 \mathrm{a}$ & $0.41 \mathrm{a}$ & $24.38 \mathrm{a}$ & $2.09 \mathrm{a}$ & $621.87 \mathrm{a}$ & \\
\hline $\max$ & 1.65 & 1.39 & 8.53 & 10.87 & 50.66 & 40.68 & 2.19 & 81.43 & 4.52 & $2,039.00$ & \\
\hline $\min$ & 0.03 & 0.04 & 0.02 & 0.28 & 0.66 & 0.84 & 0.00 & 0.96 & 0.19 & 27.44 & \\
\hline SD & 0.40 & 0.30 & 1.73 & 2.30 & 11.75 & 9.44 & 0.48 & 20.20 & 0.95 & 482.16 & \\
\hline August & V & $\mathrm{Cr}$ & $\mathrm{Co}$ & $\mathrm{Ni}$ & $\mathrm{Cu}$ & $\mathrm{Zn}$ & $\mathrm{Cd}$ & $\mathrm{Ba}$ & $\mathrm{Pb}$ & $\mathrm{Fe}$ & \\
\hline mean & $1.21 \mathrm{a}$ & $0.30 \mathrm{~b}$ & $0.63 a$ & $1.54 \mathrm{a}$ & $8.69 a$ & $17.35 \mathrm{a}$ & $0.27 \mathrm{a}$ & 46.63ab & $1.03 \mathrm{~b}$ & $368.18 b$ & \\
\hline $\max$ & 3.30 & 0.47 & 4.09 & 5.12 & 27.90 & 218.60 & 1.05 & 147.00 & 3.15 & 972.70 & \\
\hline $\min$ & 0.29 & 0.14 & 0.11 & 0.61 & 1.34 & 2.24 & 0.01 & 6.14 & 0.29 & 131.20 & \\
\hline SD & 0.86 & 0.08 & 0.76 & 0.88 & 6.96 & 42.30 & 0.27 & 45.78 & 0.58 & 175.37 & \\
\hline October & V & $\mathrm{Cr}$ & $\mathrm{Co}$ & $\mathrm{Ni}$ & $\mathrm{Cu}$ & $\mathrm{Zn}$ & $\mathrm{Cd}$ & $\mathrm{Ba}$ & $\mathrm{Pb}$ & $\mathrm{Fe}$ & As \\
\hline mean & $1.36 \mathrm{a}$ & $0.34 b$ & $1.20 \mathrm{ab}$ & 2.09ab & $11.93 \mathrm{a}$ & $90.36 \mathrm{~b}$ & $0.79 a$ & $54.69 \mathrm{~b}$ & $2.02 \mathrm{ab}$ & $404.59 b$ & $3.67 \mathrm{a}$ \\
\hline $\max$ & 2.70 & 0.85 & 7.18 & 7.87 & 64.18 & $1,826.00$ & 5.93 & 159.30 & 9.41 & 1316.00 & 17.26 \\
\hline $\min$ & 0.23 & 0.13 & 0.14 & 0.55 & 1.07 & 3.00 & 0.01 & 7.52 & 0.40 & 113.20 & 0.82 \\
\hline SD & 0.77 & 0.16 & 1.48 & 1.79 & 12.82 & 362.24 & 1.51 & 40.81 & 2.26 & 324.37 & 4.30 \\
\hline December & V & $\mathrm{Cr}$ & $\mathrm{Co}$ & $\mathrm{Ni}$ & $\mathrm{Cu}$ & $\mathrm{Zn}$ & $\mathrm{Cd}$ & $\mathrm{Ba}$ & $\mathrm{Pb}$ & $\mathrm{Fe}$ & As \\
\hline mean & $1.35 \mathrm{a}$ & $0.65 \mathrm{a}$ & $1.72 b$ & $2.91 \mathrm{~b}$ & $11.41 \mathrm{a}$ & $73.58 b$ & $2.94 \mathrm{~b}$ & $55.26 \mathrm{~b}$ & $4.94 \mathrm{c}$ & $474.26 \mathrm{ab}$ & $3.14 \mathrm{a}$ \\
\hline $\max$ & 3.79 & 1.38 & 4.29 & 5.12 & 36.01 & 423.20 & 24.20 & 132.70 & 13.77 & $2,035.00$ & 14.74 \\
\hline $\min$ & 0.26 & 0.37 & 0.11 & 0.46 & 0.96 & 3.07 & 0.01 & 7.83 & 1.18 & 109.40 & 0.40 \\
\hline SD & 0.99 & 0.21 & 1.08 & 1.25 & 9.60 & 118.83 & 6.30 & 36.63 & 2.84 & 370.69 & 3.58 \\
\hline WHO [45] & & 50 & & 70 & 2,000 & & 5 & 700 & 10 & & 10 \\
\hline $\begin{array}{l}\text { Chinese standards } \\
\text { (GB5749-2006) [36] }\end{array}$ & & 50 & & 20 & 1,000 & 1,000 & 5 & 700 & 10 & & 10 \\
\hline
\end{tabular}

Data with different letters have significant differences in rows

$\mathrm{Ba}$, and As) occurred in the upstream (S1-S4), which had the least mining and agricultural activities, while the highest levels $(25.08 \mu \mathrm{g} / \mathrm{L}, 321.43 \mu \mathrm{g} / \mathrm{L}, 5.63 \mu \mathrm{g} / \mathrm{L}$, $109.65 \mu \mathrm{g} / \mathrm{L}, 11.45 \mu \mathrm{g} / \mathrm{L}$ for $\mathrm{Cu}, \mathrm{Zn}, \mathrm{Cd}, \mathrm{Ba}$, and As) happened in the midstream of the Le'an (S9-S12), where the most violent mining activities were distributed. The midstream of the Le'an was encircled by such mining areas as a copper mine and $\mathrm{Pb}-\mathrm{Zn}$ ore, which possibly discharged abundant sewage water into the river and contributed much dissolved heavy metals content to the water environment. This indicated that these metals in surface water were possibly related to mining activities. Yu et al. [29] also found that the agricultural soil at Dexing, located in the midstream of the Le'an, had the highest $\mathrm{Cu}$ level. It was worth noting that the levels of these metals downstream of the Le'an were higher than those in the upstream, but lower than those in the midstream. The downstream of the Le'an River were the developed area of agriculture, and a great deal of fertilizer and pesticide were used. The previous studies found that frequent use of fertilizers and pesticides caused heavy metal enriching in agricultural soil, increasing heavy metal input into river and eventually destroying the aquatic environment [41-42]. Therefore, we induced that the higher levels of these metals in surface water were possibly derived from agricultural activities. It was found that concentrations of $\mathrm{Co}, \mathrm{Ni}, \mathrm{Fe}$, and $\mathrm{Cr}$ had similar spatial distributions. All highest levels of these metals happened in S5 - the site of the sewage outfall of the Dawn River. $\mathrm{V}$ and $\mathrm{Pb}$ had two peak values that were distributed in the Jishui River (the tributary of the Le'an) and the downstream of the Le'an.

Based on Fig. 2, concentrations of dissolved heavy metals in most sites were higher in the dry season than those in the wet season - especially in the mining area. Analysis of variance (ANOVA) showed that the dissolved metals in the surface water exhibited significant fluctuations that varied with different seasons, except $\mathrm{V}$ and $\mathrm{Cu}$ (Table 1). The mean total concentration of the dissolved metals (except Fe) in May, August, October, and December were $58.19 \mu \mathrm{g} / \mathrm{L}, 77.67 \mu \mathrm{g} / \mathrm{L}, 164.78 \mu \mathrm{g} / \mathrm{L}$, and $154.76 \mu \mathrm{g} / \mathrm{L}$, respectively. Total mean concentrations of heavy metals in October and December (dry season) were significantly higher than those in May and August 
(wet season). The lowest and highest total concentrations were $3.01 \mu \mathrm{g} / \mathrm{L}(\mathrm{S} 3)$ and $185.54 \mu \mathrm{g} / \mathrm{L}$ (S11) in May, $19.75 \mu \mathrm{g} / \mathrm{L}$ (S1) and $348.30 \mu \mathrm{g} / \mathrm{L}$ (S12) in August, $15.59 \mu \mathrm{g} / \mathrm{L}(\mathrm{S} 1)$ and $1988.45 \mu \mathrm{g} / \mathrm{L}(\mathrm{S} 12)$ in October, and $16.34 \mu \mathrm{g} / \mathrm{L}(\mathrm{S} 1)$ and $624.27 \mu \mathrm{g} / \mathrm{L}$ (S11) in December. As a whole, the highest total concentrations in all sampling sites concentrated from S8 to S12 - sites located in the Jishui River and significantly influenced by copper and $\mathrm{Pb}-\mathrm{Zn}$ mining activities. The levels of all metals in surface water in the dry season were significantly higher than those in the wet season and showed significant seasonality (Table 1). Dilution due to high precipitation in wet season was the most plausible explication for most of the dissolved metals owning to their lowest concentrations. Similar results were also found in other studies [43-44]. However, this diluting effect seemingly did not work for $\mathrm{Cu}$ and $\mathrm{V}$ (Table 1).

Compared mean concentrations of dissolved heavy metals in the Le'an with drinking water guidelines issued by WHO [45] and China [36] (Table 1), the concentrations of all selected metals were below the threshold. Specifically, $\mathrm{Zn}$ concentrations of site 12 in October exceeded the threshold established by China, and $\mathrm{Pb}$ concentrations of site 18 in October were comparable to the threshold issued by China. In December, $\mathrm{Cd}$ concentrations from site 9 to site
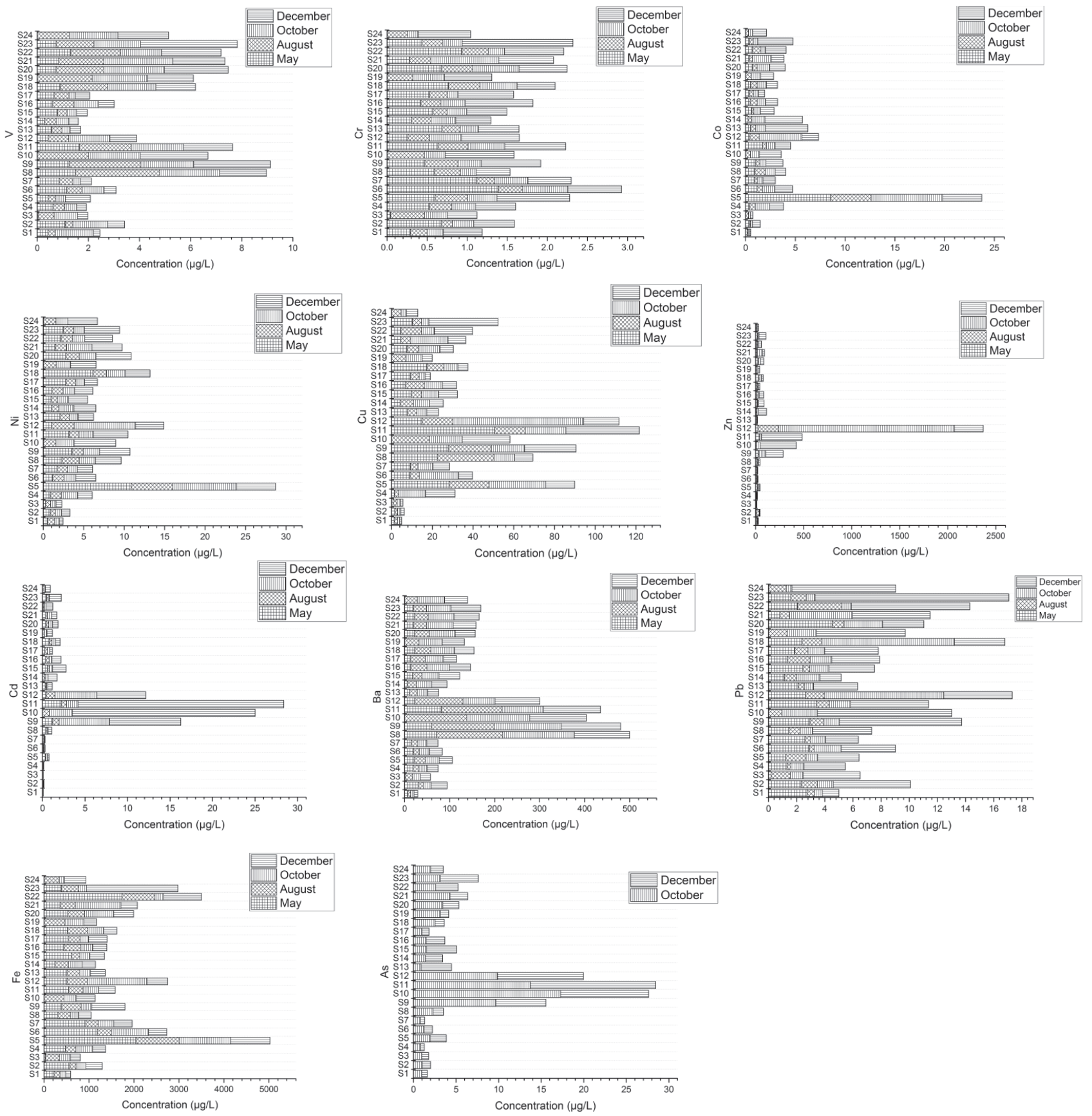

Fig. 2. Seasonal data of selected heavy metals along sampling sites of the Le'an River. 


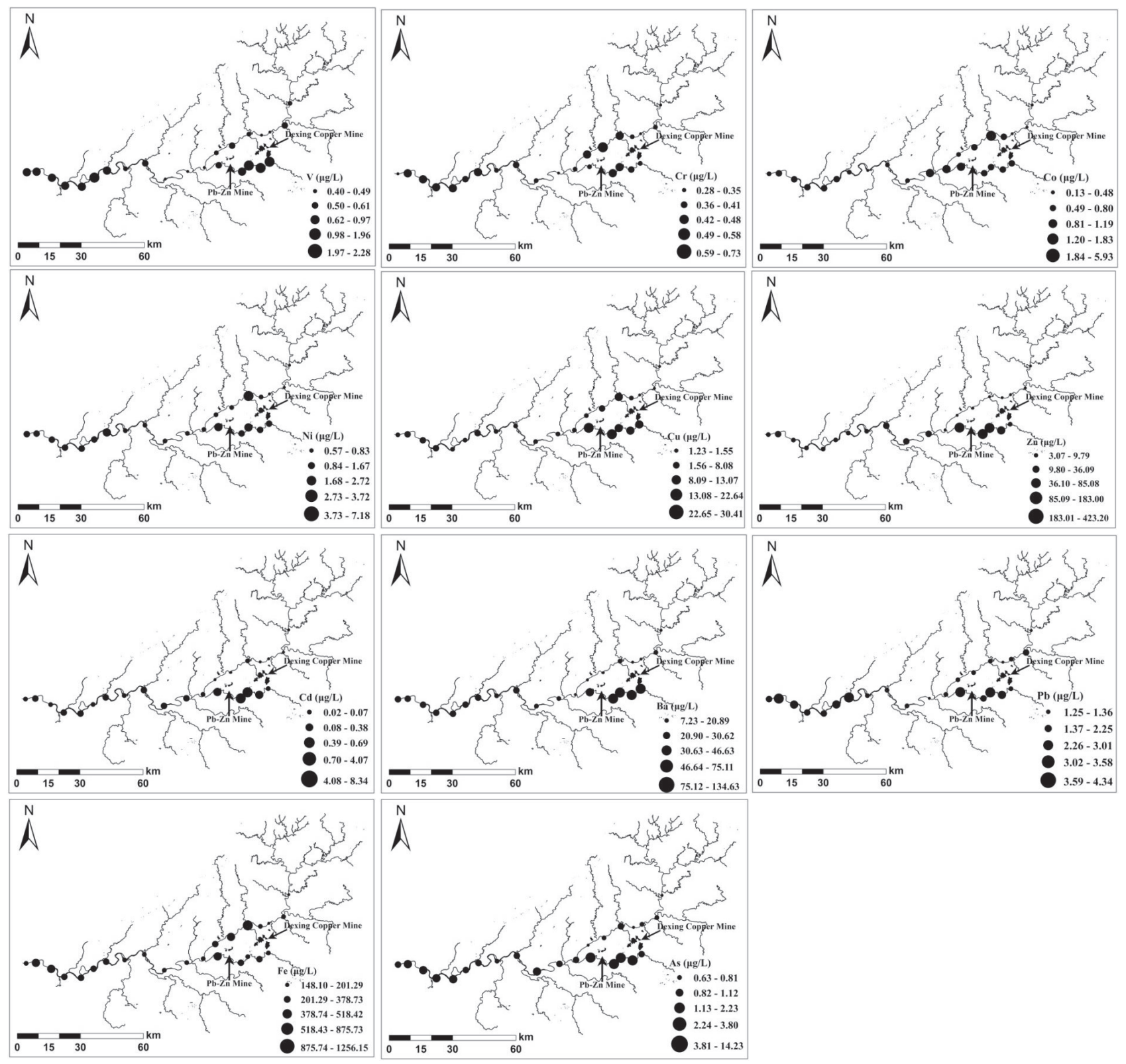

Fig. 3. Distribution of mean dissolved heavy metals concentrations along Le'an River sampling sites.

12 were higher than those values set by China, and $\mathrm{Pb}$ concentration at site 10 was comparable to the threshold issued by China.

\section{Integrated Approach of Heavy Metal Pollution Index}

To evaluate heavy metal pollution indices of river water we calculated heavy metal pollution index (HPI) and metal pollution index (MPI). The results of HPI and MPI were presented in Figs 4-5. The mean HPI in May, August, October, and December were 54.81, 45.68, 72.75, and 161.80 , respectively. The critical pollution index value is 100 , below which the overall pollution level should be considered acceptable for an aquatic ecosystem [46]. In August, HPI values in all sample sites were below 100, and the pollution level was considered acceptable for the aquatic ecosystem. In May, all of the sites were below 100, except for S9 and S11, which were 114.98 and 226.12, respectively. In the dry season (October and December), the aquatic ecosystems in the sites from S9 to S12 and S23 suffered high pressure from dissolved metals with HPI higher than 100. And the mean HPI values from S9 to $\mathrm{S} 12$ ranged from 230.55 to 707.94 . The pressure was higher in December than that in October due to the higher HPI values. The MPI values presented similar results that dry season and showed higher MPI than that in the wet season. Specifically, ater quality in sites S9 to S12 were strongly affected or seriously affected by the dissolved metals based on MPI standards. The surface water of all sites except S11 was clean in May. In October, waters in S10 and S18 were slightly affected, S9 and S12 were at moderate level, while water in other sites was quite clean. Most serious pollution happened in December. 

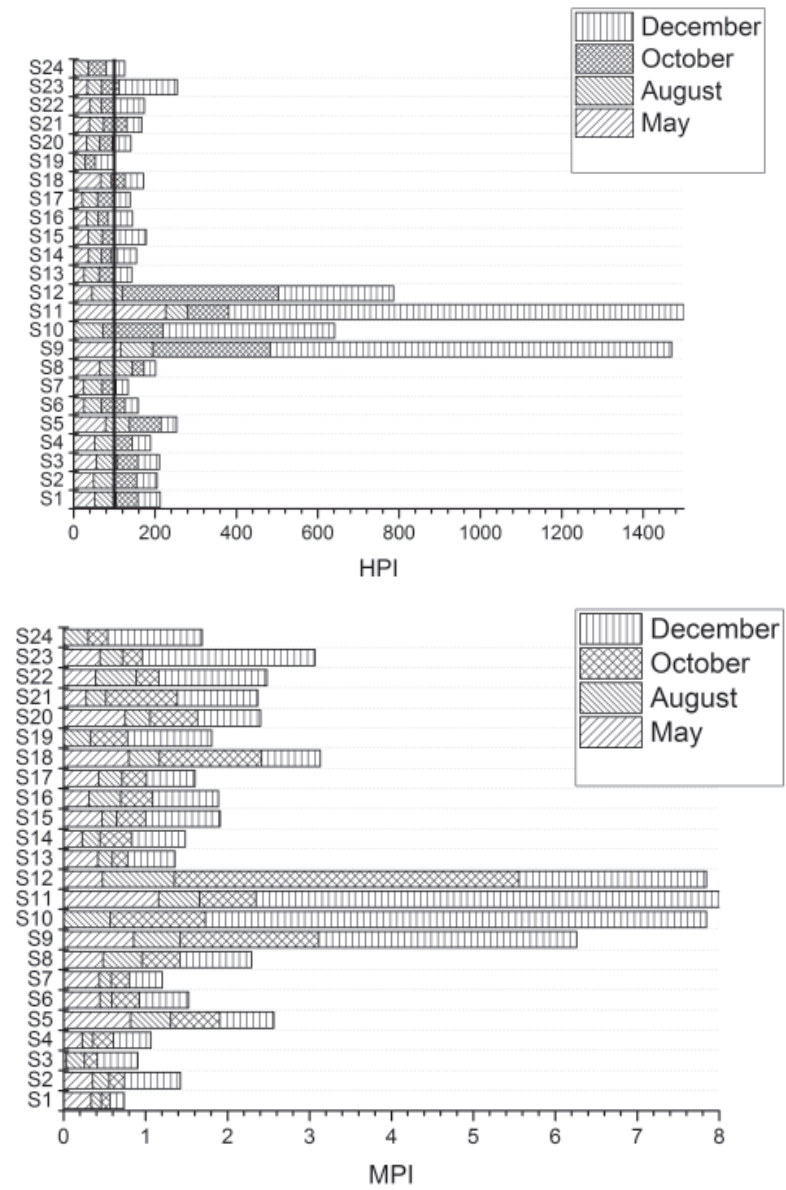

Fig. 4. HPI and MPI of the dissolved metals for 4 seasons and 24 sites along the Le'an River.

Water quality in S15, S19, S21, S22, and S24 was slightly affected, S12 and S23 were moderately affected, S9 was strongly affected, and S10 and S11 were seriously affected. This indicated that surface water quality from the Le'an suffered certain pressure from the dissolved metals, especially in the midstream and dry seasons.

\section{Potential Human Health Risk Assessment}

We evaluated the potential risk of human health for water ingestion through oral consumption and dermal absorption of dissolved metals were evaluated. Adults and children in this study were the two groups of population to evaluate potential heavy metal health risk. In order to calculate the chronic daily index (CDI), hazard quotient (HQ), and hazard index (HI), the mean concentrations of four campaign samples were used. The values of $\mathrm{HQ}$ and HI are presented in Table 2.

The order of mean $\mathrm{HQ}_{\text {ingestion }}$ of both children and adults were $\mathrm{As}>\mathrm{Co}>\mathrm{Cd}>\mathrm{Pb}>\mathrm{Cu}>\mathrm{Zn}>\mathrm{V}>\mathrm{Ba}>\mathrm{Cr}>\mathrm{Ni}$, and the values of $\mathrm{HQ}_{\text {ingestion }}$ for children were higher than those for adults. Mean values of $\mathrm{HQ}_{\text {ingestion }}$ in 24 sampling sites for children and adult were less than 1. Specifically, the higher values of $\mathrm{HQ}_{\text {ingestion }}$ were observed at $\mathrm{S} 8$ and $\mathrm{S} 9$ for V, S5 and S6 for Cr, S5 and S12 for Co, S5 and S12 for
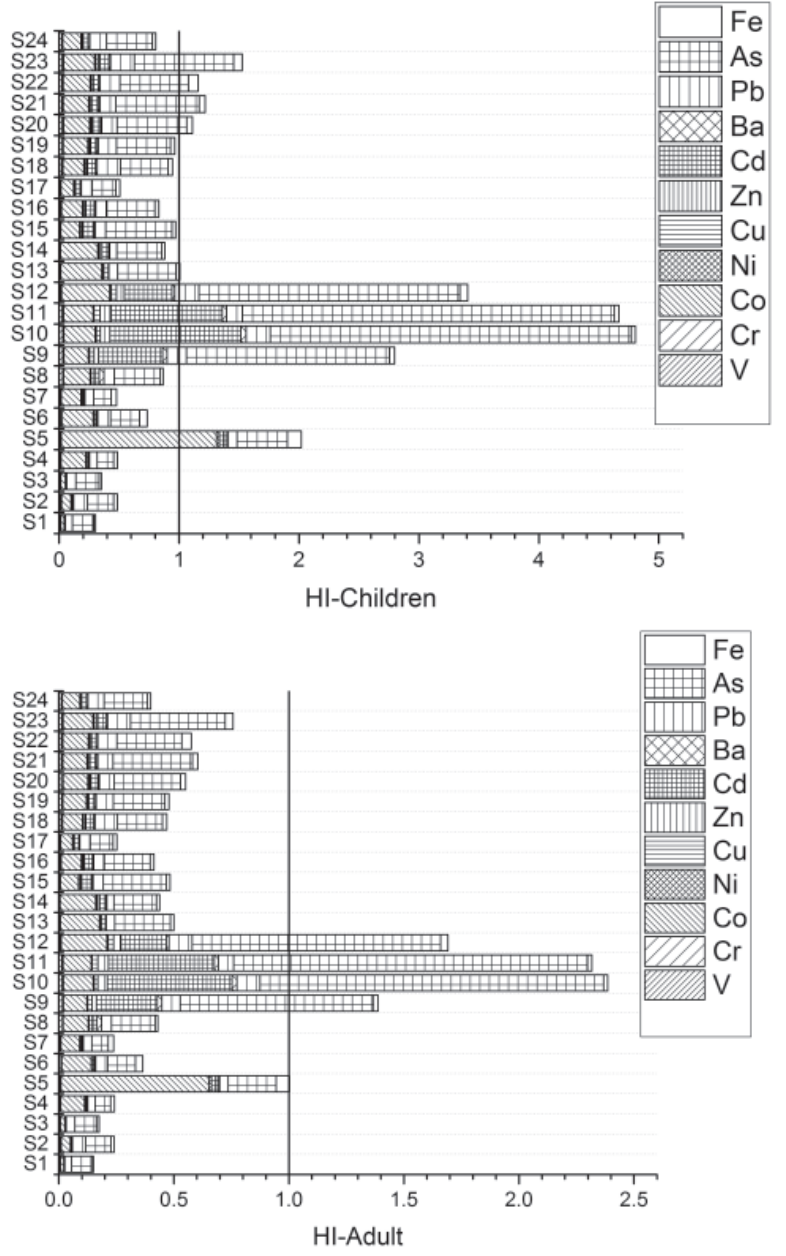

Fig. 5. Hazard index of the mixed heavy metals in surface water from the Le'an River.

$\mathrm{Ni}, \mathrm{S} 11$ and $\mathrm{S} 12$ for $\mathrm{Cu}, \mathrm{S} 11$ and $\mathrm{S} 12$ for $\mathrm{Zn}, \mathrm{S} 10$ and $\mathrm{S} 11$ for $\mathrm{Cd}, \mathrm{S} 10$ and $\mathrm{S} 8$ for $\mathrm{Ba}, \mathrm{S} 10$ and $\mathrm{S} 23$ for $\mathrm{Pb}$, and $\mathrm{S} 11$ and S10 for As. The $\mathrm{HQ}_{\text {ingestion }}$ values of $\mathrm{Co}$ (S5) and $\mathrm{Cd}$ (S10) and As (from S9 to S12) for children, and As (from S10 to S12) for adults were higher than 1, which indicated that it had significant harm to the human body due to oral consumption of water in some Le'an sites. The $\mathrm{HQ}_{\text {dermal }}$ values for the children and adults had the same order and ranked as $\mathrm{As}>\mathrm{Co}>\mathrm{Cd}>\mathrm{Pb}>\mathrm{Cr}>\mathrm{Ni}>\mathrm{V}>\mathrm{Ba}>\mathrm{Cu}>\mathrm{Zn}$. The highest $\mathrm{HQ}_{\text {dermal }}$ values of $\mathrm{V}, \mathrm{Cr}, \mathrm{Co}, \mathrm{Ni}, \mathrm{Cu}, \mathrm{Zn}, \mathrm{Cd}, \mathrm{Ba}$, $\mathrm{Pb}$, and As appeared in S10, S6, S5, S5, S11, S11, S9, S9, $\mathrm{S} 9$, and S11, respectively. Compared to $\mathrm{HQ}_{\text {ingestion }}, \mathrm{HQ}_{\text {dermal }}$ was considered as a negligible contribution for human health risk, which was consistent with the results in the other previous study [43]. Therefore, oral consumption of the dissolved metals was the main pathway for human noncarcinogenic risk in the Le'an. $\mathrm{HQ}_{\text {ingestion }}$ of As was nearly 1, implying that As may cause adverse health effects and potential non-carcinogenic concern. Previous studies reported that high As intake might cause adverse health effects, including hypertension, neuropathy, diabetes, skin lesions, and cardiovascular and cerebrovascular diseases [47].

The HI index of selected heavy metal was calculated 
Table 2. Reference dose and hazard quotient for each metal of the Le'an River.

\begin{tabular}{|c|c|c|c|c|c|c|c|c|c|}
\hline \multirow{2}{*}{ Metal } & \multirow{2}{*}{$\begin{array}{l}\text { Concentration } \\
(\mu \mathrm{g} / \mathrm{L})\end{array}$} & \multirow{2}{*}{$\begin{array}{c}\mathrm{RfD}_{\text {dermal }} \\
(\mu \mathrm{g} / \mathrm{kg} / \text { day })\end{array}$} & \multirow{2}{*}{$\begin{array}{c}\mathrm{RfD}_{\text {ing }} \\
(\mu \mathrm{g} / \mathrm{kg} / \text { day })\end{array}$} & \multicolumn{2}{|c|}{$\mathrm{HQ}_{\text {ingenstion }}$} & \multicolumn{2}{|c|}{$\mathrm{HQ}_{\text {dermal }}$} & \multicolumn{2}{|c|}{ HI } \\
\hline & & & & Child & Adult & Child & Adult & Child & Adult \\
\hline V & 1.22 & 0.13 & 5 & $1.59 \mathrm{E}-02$ & 7.90E-03 & $1.56 \mathrm{E}-07$ & $1.44 \mathrm{E}-07$ & $1.59 \mathrm{E}-02$ & $7.90 \mathrm{E}-03$ \\
\hline $\mathrm{Cr}$ & 0.46 & 0.075 & 3 & $1.01 \mathrm{E}-02$ & $5.00 \mathrm{E}-03$ & $2.06 \mathrm{E}-07$ & $1.90 \mathrm{E}-07$ & $1.01 \mathrm{E}-02$ & $5.00 \mathrm{E}-03$ \\
\hline $\mathrm{Co}$ & 1.13 & 0.06 & 0.3 & $2.47 \mathrm{E}-01$ & $1.22 \mathrm{E}-01$ & $1.26 \mathrm{E}-06$ & $1.16 \mathrm{E}-06$ & $2.47 \mathrm{E}-01$ & $1.22 \mathrm{E}-01$ \\
\hline $\mathrm{Ni}$ & 2.22 & 0.8 & 20 & 7.27E-03 & $3.61 \mathrm{E}-03$ & $1.86 \mathrm{E}-07$ & $1.71 \mathrm{E}-07$ & 7.27E-03 & $3.61 \mathrm{E}-03$ \\
\hline $\mathrm{Cu}$ & 10.92 & 8 & 40 & $1.78 \mathrm{E}-02$ & 8.86E-03 & $2.28 \mathrm{E}-08$ & $2.10 \mathrm{E}-08$ & $1.78 \mathrm{E}-02$ & $8.86 \mathrm{E}-03$ \\
\hline $\mathrm{Zn}$ & 73.58 & 60 & 300 & $1.60 \mathrm{E}-02$ & $7.96 \mathrm{E}-03$ & $1.23 \mathrm{E}-08$ & $1.13 \mathrm{E}-08$ & $1.60 \mathrm{E}-02$ & $7.96 \mathrm{E}-03$ \\
\hline $\mathrm{Cd}$ & 1.18 & 0.025 & 0.3 & $1.55 \mathrm{E}-01$ & 7.69E-02 & 7.91E-07 & $7.30 \mathrm{E}-07$ & $1.55 \mathrm{E}-01$ & 7.69E-02 \\
\hline $\mathrm{Ba}$ & 46.83 & 14 & 200 & $1.53 \mathrm{E}-02$ & $7.60 \mathrm{E}-03$ & $5.58 \mathrm{E}-08$ & $5.15 \mathrm{E}-08$ & $1.53 \mathrm{E}-02$ & 7.60E-03 \\
\hline $\mathrm{Pb}$ & 2.57 & 0.42 & 1.4 & $1.20 \mathrm{E}-01$ & $5.95 \mathrm{E}-02$ & $4.08 \mathrm{E}-07$ & $3.76 \mathrm{E}-07$ & $1.20 \mathrm{E}-01$ & $5.95 \mathrm{E}-02$ \\
\hline As & 3.40 & 0.285 & 0.3 & $7.42 \mathrm{E}-01$ & $3.68 \mathrm{E}-01$ & $1.99 \mathrm{E}-06$ & $1.84 \mathrm{E}-06$ & 7.42E-01 & $3.68 \mathrm{E}-01$ \\
\hline $\mathrm{Fe}$ & 467.23 & 140 & 700 & 4.36E-02 & $2.17 \mathrm{E}-02$ & $5.57 \mathrm{E}-05$ & $5.14 \mathrm{E}-05$ & $4.36 \mathrm{E}-02$ & $2.17 \mathrm{E}-02$ \\
\hline
\end{tabular}

and presented in Table 5 and Fig. 5. The mean HI of all heavy metals both for child and adult were within the safe limit. The orders of HI both for child and adult were $\mathrm{As}>\mathrm{Co}>\mathrm{Cd}>\mathrm{Pb}>\mathrm{Cu}>\mathrm{Zn}>\mathrm{V}>\mathrm{Ba}>\mathrm{Cr}>\mathrm{Ni}$. Mean HI values for children were significantly higher than those for adults, indicating that children in the Le'an River basin suffered a higher health risk. Heavy metals of $\mathrm{As}, \mathrm{Co}, \mathrm{Pb}$, and $\mathrm{Cd}$ contributed a high percentage to non-carcinogenic risk for children and adults. For children, HI of dissolved heavy metals exceed one for Co (S5), Cd (S10 and S11), and As (S9, S10, S11, and S12). For adults, HI of As exceeded the limit threshold in S10 and S11. Sites with high HI values for both children and adults were mainly distributed in mining areas (from S9 to S12; Fig. 5), and the HI values for children were basically twice as much as those for adults. This indicated that the people distributed in mining areas suffered high health risks and needed to be pay more attention. Just like in the Ganjiang River, As undoubtedly was the most important pollutant in the Le'an [43]. The main traditional purification processes - including coagulation-sedimentation, sand filtration, and disinfection - were employed for purification in China, which hardly removed the arsenic pollutant [48]. Therefore, we must pay more attention to arsenic for local residents in mining areas - especially for sensitive children.

Using Multivariate Statistical Analysis to Identify Sources of Heavy Metals

Multivariate statistical analysis such as principal component analysis (PCA), correlation coefficient analysis (CCA), and cluster analysis (CA) were used to identify the possible sources of heavy metals in the Le'an River. PCA is well developed as a statistical technique to identify the different groups of heavy metals in river water and thus could be considered as having a similar behavior and a common origin when heavy metals are in the same group $[9,44,49]$. In this study, the potential sources of dissolved heavy metals were explored by using PCA and CCA analysis combining their spatial distributions. Results of PCA are presented in Table 3. PCA of the normalized dataset extracted a varimax rotation of PCs with eigenvalues $>1$, and there were 3 PCs explaining about $86.419 \%$ of the total variances of information contained in the original dataset. The values of KMO and Bartlett were 0.591 and 0.000 , respectively. The first component (PC1) explained $39.352 \%$ of the total variance and had strong positive loading on $\mathrm{Cu}, \mathrm{Zn}, \mathrm{Cd}$, $\mathrm{Ba}$, and As. The second component (PC2) explained $28.62 \%$ of the total variance and had strong positive loading on $\mathrm{Co}, \mathrm{Ni}$, and $\mathrm{Fe}$, and moderate loading on $\mathrm{Cr}$ and $\mathrm{Cu}$. The third component (PC3) explained 18.564\% of the total variance and had strong positive loading on $\mathrm{V}$ and $\mathrm{Pb}$, and moderate loading on $\mathrm{Cr}$.

Similar information from PCA was provided based on CCA among heavy metals in the Le'an (Table 4). The correlation matrix showed that there were a number of great positive correlations among the selected heavy metals. Heavy metals pairs $\mathrm{V}-\mathrm{Cu}, \mathrm{V}-\mathrm{Cd}, \mathrm{V}-\mathrm{As}, \mathrm{Cr}-\mathrm{Ni}$, $\mathrm{Co}-\mathrm{Cu}, \mathrm{Cu}-\mathrm{Pb}, \mathrm{Zn}-\mathrm{Pb}, \mathrm{Cd}-\mathrm{Pb}, \mathrm{Ba}-\mathrm{Pb}$, and $\mathrm{Fe}-\mathrm{Cu}$ had a significantly positive correlation at the $\mathrm{p}<0.05$ level, whereas the heavy metals pairs $\mathrm{V}-\mathrm{Ba}, \mathrm{V}-\mathrm{Pb}, \mathrm{Co}-\mathrm{Ni}$, Ni$\mathrm{Cu}, \mathrm{Cu}-\mathrm{Zn}, \mathrm{Cu}-\mathrm{Cd}, \mathrm{Cu}-\mathrm{Ba}, \mathrm{Cu}-\mathrm{As}, \mathrm{Zn}-\mathrm{Cd}, \mathrm{Zn}-\mathrm{Ba}, \mathrm{Zn}-\mathrm{As}$, $\mathrm{Cd}-\mathrm{Ba}$, Cd-As, Ba-As, Pb-As, Fe-Cr, Fe-Co, and $\mathrm{Fe}-\mathrm{Ni}$ had a significantly positive correlation at $\mathrm{p}<0.01$. Based on previous studies [50-51], it might be deduced that the heavy metals had common, mutual dependence and identical behavior or were affected by the same factor(s) during transport if the correlation coefficient between the elements was positive. The observed correlation matrix basically supported the result from the PCA for dissolved metals in surface water. 
Table 3. Principal component loadings (varimax normalized) for heavy metals in Le'an River water.

\begin{tabular}{|c|c|c|c|}
\hline Mean & PC1 & PC2 & PC3 \\
\hline $\mathrm{V}$ & 0.381 & -0.44 & $\mathbf{0 . 8 2 0}$ \\
\hline $\mathrm{Cr}$ & -0.003 & $\mathbf{0 . 5 6 0}$ & $\mathbf{0 . 5 7 4}$ \\
\hline $\mathrm{Co}$ & 0.080 & $\mathbf{0 . 9 4 3}$ & -0.223 \\
\hline $\mathrm{Ni}$ & 0.252 & $\mathbf{0 . 8 9 1}$ & 0.109 \\
\hline $\mathrm{Cu}$ & $\mathbf{0 . 7 7 5}$ & $\mathbf{0 . 5 2 3}$ & 0.170 \\
\hline $\mathrm{Zn}$ & $\mathbf{0 . 9 5 8}$ & 0.047 & 0.131 \\
\hline $\mathrm{Cd}$ & $\mathbf{0 . 9 4 3}$ & 0.003 & 0.189 \\
\hline $\mathrm{Ba}$ & $\mathbf{0 . 8 1 6}$ & -0.005 & 0.384 \\
\hline $\mathrm{Pb}$ & 0.370 & 0.102 & $\mathbf{0 . 8 0 0}$ \\
\hline $\mathrm{As}$ & $\mathbf{0 . 9 4 5}$ & 0.091 & 0.233 \\
\hline $\mathrm{Fe}$ & -0.094 & $\mathbf{0 . 9 2 5}$ & 0.232 \\
\hline Eigenvalues & 39.352 & 67.972 & 86.536 \\
\hline Cumulative \% & 4.329 & 3.148 & 2.042 \\
\hline & & &
\end{tabular}

Based on the results of PCA, Pearson correlation analysis, and spatial distribution, the sources of selected heavy metals in surface water from the Le'an could be identified. The first principal components (PC1), including $\mathrm{Cu}, \mathrm{Zn}, \mathrm{Cd}, \mathrm{Ba}$, and $\mathrm{As}$, were derived from mining exploitation. The second principal components (PC2), including $\mathrm{Cr}, \mathrm{Co}, \mathrm{Ni}$, and $\mathrm{Fe}$, were mainly lithogenic. The third principal components (PC3) containing $\mathrm{V}$ and $\mathrm{Pb}$ were caused by mining exploitation and agricultural activities.

The high level of $\mathrm{Cu}, \mathrm{Zn}, \mathrm{Cd}, \mathrm{Ba}$, and $\mathrm{As}$ were distributed in the Dexing area, which was located in the midstream Le'an River. The Dexing area suffered huge pressure from resource exploitation such as the Dexing Copper Mine, Fujiawu Copper Mine, and $\mathrm{Pb}-\mathrm{Zn}$ ore, and mineral wastewater from these mines were discharged into the river and became important sources of $\mathrm{Cu}, \mathrm{Zn}$, $\mathrm{Cd}, \mathrm{Ba}$, and As. Previous investigations showed serious $\mathrm{Cu}$ enrichment in the Dexing area due to mining activities $[30,52]$. Industrial activities accompanying mining introduced loads of As to the environment [53]. William et al. [54] analyzed the effects of industrial activities on $\mathrm{Zn}$ emissions and found that nonferrous metal refining resulted in a great contribution of $\mathrm{Zn}$ emissions to the environment. The previous evidence also indicated that mining and metal smelting could cause high Cd levels in the environment [55]. Therefore, we confirmed that $\mathrm{Cu}, \mathrm{Zn}, \mathrm{Cd}$, and As were closely in relation with mining activities. Although there was enough evidence that $\mathrm{Ba}$ had some relationship with mining activities, the similar spatial distribution and close relationship with $\mathrm{Cu}, \mathrm{Zn}$, $\mathrm{Cd}$, and As proved by PCA and CCA confirmed that it had a close relationship with mining.
Fe was found to be abundant in the earth, and the second principal ( $\mathrm{PC} 2$ ), including $\mathrm{Co}, \mathrm{Ni}$, and $\mathrm{Fe}$, were therefore assumed to originate from natural contributions [56]. The previous also reported that rock weathering was the source of Ni in the environment [57-59]. However, the levels of these metals were high in S5 possibly due to the violent mining activities or high geological background levels.

The third principal components (PC3), comprised of $\mathrm{V}, \mathrm{Cr}$, and $\mathrm{Pb}$, had mixed sources from agriculture and mining. The result from spatial distributions demonstrated that $\mathrm{V}, \mathrm{Cr}$, and $\mathrm{Pb}$ in sites from S18 to S24 were mainly derived from mining activities, and these metals in sites from S18 to S24 mainly originated from agricultural and urban activities. Previous studies proved that agricultural activities had significant effects on concentrations of the dissolved metals [60]. In China, fertilizers always were regarded as the main source of $\mathrm{Cr}$ and $\mathrm{Pb}$ in farmland [61]. Additionally, previous studies reported that both mining and agricultural processes input $\mathrm{V}$ into the environment. [62]. A huge percentage (about $50.43 \%$ ) of agricultural land was distributed downstream of the Le'an, which possibly resulted in high inputs of fertilizers and pesticides containing inorganic elements into the river.

The dendrogram resulting from CA showed four main categories (groups), i,e., cluster 1 (sites 1-4, 7-9, 13-21, and 24), cluster 2 (sites 10-12), cluster 3 (sites 6, 22-23), and cluster 4 (site 5) (Fig. 6). Based on mean concentrations of dissolved heavy metals in four clusters (Table 5), concentrations of $\mathrm{Cu}, \mathrm{Zn}, \mathrm{Cd}, \mathrm{Ba}, \mathrm{As}, \mathrm{Ni}, \mathrm{Co}$, and $\mathrm{Fe}$ showed significant differences among four clusters. Cluster 2 had the highest concentrations of $\mathrm{Cu}, \mathrm{Zn}, \mathrm{Cd}$, $\mathrm{Ba}$, and $\mathrm{As}$, and cluster 4 had the highest concentrations of $\mathrm{Ni}, \mathrm{Co}$, and $\mathrm{Fe}$. In cluster 2, concentrations of $\mathrm{Cd}$ and As were higher than their drinking water quality of WHO and Chinese standards. Furthermore, sites in

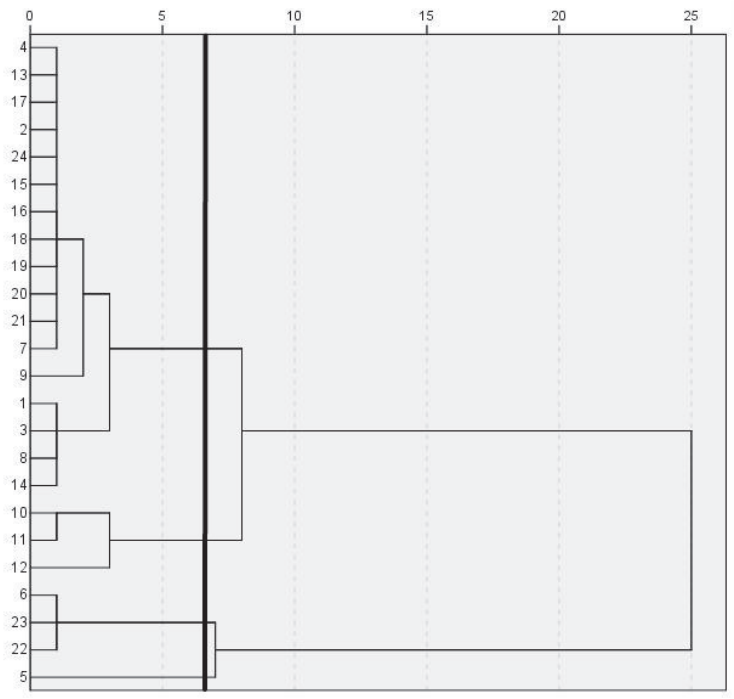

Fig. 6. Dendrogram showing clustering of sampling sites according to Ward's method using squared Euclidean distance. 
Table 4. Pearson correlation matrix of dissolved heavy metals in the Le'an River.

\begin{tabular}{|c|c|c|c|c|c|c|c|c|c|c|c|}
\hline & $\mathrm{V}$ & $\mathrm{Cr}$ & $\mathrm{Co}$ & $\mathrm{Ni}$ & $\mathrm{Cu}$ & $\mathrm{Zn}$ & $\mathrm{Cd}$ & $\mathrm{Ba}$ & $\mathrm{Pb}$ & $\mathrm{As}$ & $\mathrm{Fe}$ \\
\hline $\mathrm{V}$ & 1 & & & & & & & & & & \\
\hline $\mathrm{Cr}$ & 0.312 & 1 & & & & & & & & & \\
\hline $\mathrm{Co}$ & -0.123 & 0.322 & 1 & & & & & & & & \\
\hline $\mathrm{Ni}$ & 0.231 & $0.413^{*}$ & $0.883^{* *}$ & 1 & & & & & & & \\
\hline $\mathrm{Cu}$ & $0.420^{*}$ & 0.392 & $0.487^{*}$ & $0.660^{* *}$ & 1 & & & & & & \\
\hline $\mathrm{Zn}$ & 0.392 & 0.165 & 0.058 & 0.247 & $0.775^{* *}$ & 1 & & & & & \\
\hline $\mathrm{Cd}$ & $0.468^{*}$ & 0.205 & 0.029 & 0.23 & $0.706^{* *}$ & $0.953^{* *}$ & 1 & & & & \\
\hline $\mathrm{Ba}$ & $0.743^{* *}$ & 0.144 & 0.016 & 0.296 & $0.740^{* *}$ & $0.738^{* *}$ & $0.790^{* *}$ & 1 & & & \\
\hline $\mathrm{Pb}$ & $0.708^{* *}$ & 0.379 & -0.053 & 0.312 & $0.440^{*}$ & $0.504^{*}$ & $0.487^{*}$ & $0.511^{*}$ & & 1 & \\
\hline $\mathrm{As}$ & $0.493^{*}$ & 0.232 & 0.091 & 0.305 & $0.796^{* *}$ & $0.982^{* *}$ & $0.965^{* *}$ & $0.780^{* *}$ & $0.574^{* *}$ & 1 & 1 \\
\hline $\mathrm{Fe}$ & 0.065 & $0.654^{* *}$ & $0.782^{* *}$ & $0.760^{* *}$ & $0.453^{*}$ & 0.022 & -0.034 & -0.036 & 0.276 & 0.08 & 1 \\
\hline
\end{tabular}

${ }^{*} \mathrm{p}<0.05$ (2-tailed)

${ }^{* *} \mathrm{p}<0.01$ (2-tailed)

the same category were regarded as having the same source of pollution [63]. We believed that the sites in clusters 2 and 4 were predominantly influenced by mining activities. Sites in cluster 3 were significantly influenced by agricultural and urban activities, and water quality was relatively clean and mainly derived from geogenic sources.

\section{Conclusions}

To study the sources and levels of dissolved metals along the Le'an River we applied multivariate statistical techniques and scientific indices. There was significant seasonality of dissolved heavy metals in the Le'an River

Table 5. Mean concentrations of dissolved heavy metals in four clusters of the Le'an River Basin $(\mu \mathrm{g} / \mathrm{L})$.

\begin{tabular}{|c|c|c|c|c|}
\hline & Cluster1 & Cluster2 & Cluster3 & Cluster4 \\
\hline $\mathrm{V}$ & 1.12 & 1.70 & 1.51 & 0.52 \\
\hline $\mathrm{Cr}$ & 0.42 & 0.50 & 0.62 & 0.57 \\
\hline $\mathrm{Co}$ & 0.81 & 1.38 & 1.13 & 5.93 \\
\hline $\mathrm{Ni}$ & 1.81 & 3.11 & 2.04 & 7.18 \\
\hline $\mathrm{Cu}$ & 7.58 & 25.90 & 10.98 & 22.48 \\
\hline $\mathrm{Zn}$ & 31.90 & 367.57 & 37.04 & 9.79 \\
\hline $\mathrm{Cd}$ & 0.52 & 6.16 & 0.31 & 0.19 \\
\hline $\mathrm{Ba}$ & 39.66 & 106.18 & 34.84 & 26.51 \\
\hline $\mathrm{Pb}$ & 2.26 & 3.84 & 3.37 & 1.61 \\
\hline $\mathrm{As}$ & 2.01 & 12.67 & 2.51 & 1.92 \\
\hline $\mathrm{Fe}$ & 352.74 & 487.24 & 767.43 & 1256.15 \\
\hline
\end{tabular}

and the higher level happened in the wet season due to the dilution effect of precipitation. Spatially, high levels of selected dissolved metals were distributed in the midstream and downstream of the Le'an, which suffered from mining and agricultural activities. It was found that water quality from sites S9-S12 suffered from serious pollution based on the calculated HPI and MPI. Human health risk assessment indicated that $\mathrm{As}, \mathrm{Co}$, and $\mathrm{Cd}$ were the major contributors to the exposure risk of the local inhabitants. Human health risk from the dissolved metals was below the safe limit except for $\mathrm{Cd}$ and As for children and As for adults in midstream Le'an. The exposure risks of the adults were less sensitive compared to the children, and oral ingestion was the primary exposure pathway. The spatial distributions, scientific indices, and multivariate statistical analyses indicated that $\mathrm{Cu}, \mathrm{Zn}, \mathrm{Cd}, \mathrm{Ba}$, and $\mathrm{As}$ mainly originated from mining activities; $\mathrm{V}, \mathrm{Cr}$, and $\mathrm{Pb}$ had mixed sources from agricultural and mining activities; and $\mathrm{Co}, \mathrm{Ni}$, and $\mathrm{Fe}$ were caused by natural contributions. Hierarchical agglomerative CA grouped all the sampling sites into four clusters based on the data set of HI, HPI, and MPI values. In cluster 2, concentrations of $\mathrm{Cd}$ and As were higher than drinking water quality of WHO and Chinese standards. Clusters 2 and 4 were predominantly influenced by mining activities. Sites in cluster 3 were significantly influenced by both agricultural and urban activities, and sites in cluster 1 were mainly caused by anthropogenic activities and geogenic sources.

\section{Acknowledgements}

This research was funded by the National Natural Science Foundation of China (Nos. 41361018 and 41401587), the Science and Technology Research Project of Jiangxi Provincial Education Department 
(No. GJJ160276), the Postdoctoral Preferred Fund of Jiangxi Province (No. 2014KY42), and the Young Talents Cultivation Funding Project of Jiangxi Normal University. We also would like to thank the anonymous reviewers for their valuable comments that greatly improved the manuscript.

\section{References}

1. LIAO J., WEN Z., RU X., CHEN J., WU H., WEI C. Distribution and migration of heavy metals in soil and crops affected by acid mine drainage: Public health implications in Guangdong Province, China. Ecotoxicology and Environmental Safety. 124, 460, 2016.

2. HORVAT M., NOLDE N., FAJON V., JEREB V., LOGAR M., LOJEN S., JACIMOVIC R., FALNOQA I., LIYA Q., FAQANELI J., DROBNE D. Total mercury, methylmercury and selenium in mercury polluted areas in the province Guizhou, China. Science of the Total Environment. 304, 231, 2003.

3. JI K., KIM J., LEE M., PARK S., KWON H., CHEONG H., JANG J., KIM D., YU S., KIM Y., LEE K. Assessment of exposure to heavy metals and health risks among residents near abandoned metal mines in Goseong, Korea. Environmental Pollution. 178, 322, 2013.

4. WILLIAMS P., LEI M., SUN G., HUANG Q., LU Y., DEACON C., MEHARG A., ZHU Y. Occurrence and partitioning of cadmium, arsenic and lead in mine impacted paddy rice: Hunan, China. Environmental Science \& Technology. 43, 637, 2009.

5. ZHANG H., JIANG Y., YANG T., WANG M., SHI G., DING M. Heavy Metal Concentrations and Risk Assessment of Sediments and Surface Water. Polish Journal of Environmental Studies. 4, 1529, 2016.

6. ZHUANG P., MCBRIDE M., XIA H., LI N., LI Z. Health risk from heavy metals via consumption of food crops in the vicinity of Dabaoshan mine, South China. Science of the Total Environment. 407 (5), 1551, 2009.

7. PAPE P., AYRAULT S., QUANTIN C. Trace element behavior and partition versus urbanization gradient in an urban river (Orge River, France). Journal of Hydrology. 472473, 99, 2012.

8. VAROL M., GOKOT B., BEKLEYEN A. Dissolved heavy metals in the Tigris River (Turkey): spatial and temporal variations. Environmental Science and Pollution Research. 20, 6096, 2013.

9. BU H., WANG W., SONG X., ZHANG Q. Characteristics and source apportionment of dissolved trace elements in the Jinshui River of the South Qinling Mts., China. Environmental Science and Pollution Research. 22, 14248, 2015.

10. WENG N., WANG W. Variations of trace metals in two estuarine environments with contrasting pollution histories. Science of the Total Environment. 485-486, 604, 2014.

11. MACKLIN M., BREWER P., BALTEANU D., COULTHARD T., DRIGA B., HOWARD A., ZAHARIA $\mathrm{S}$. The long term fate and environmental significance of contaminant metals released by the January and March 2000 mining tailings dam failure in Maramures County, upper Tisa basin, Romania, Applied Geochemistry. 18, 241, 2003.

12. BIRD G., BREWER P., MACKLIN M., BALTEANU D., DRIGA B., SERBAN M., ZAHARIA S. The solid state partitioning of contaminant metals and As in river channel sediments of the mining affected Tisa drainage basin, north-western Romania and eastern Hungary, Applied Geochemistry. 18, 1583, 2003.

13. VENUGOPAL T., GIRIDHARAN L., JAYAPRAKASH $M$. Characterization and risk assessment studies of bed sediments of River Adyar-an application of speciation study. International Journal of Environmental Research. 3, 581, 2009.

14. HEROJEET R., RISHI M, KISHORE N. Integrated approach of heavy metal pollution indices and complexity quantification using chemometric models in the Sirsa Basin, Nalagarh valley, Himachal Pradesh, India. Chinese Journal of Geochemistry. 34 (4), 620, 2015.

15. REZA R., SINGH G. Heavy metal contamination and its indexing approach for river water. International Journal of Environmental Science and Technology. 7, 785, 2010.

16. ABDULLAH E.J. Quality assessment for Shatt Al-Arab river using heavy metal pollution index and metal index. Journal of Environment and Earth Science. 3 (5), 114, 2013.

17. AKTAR M., PARAMASIVAM M., GANGULY M., PURKAIT S., SENGUPTA D. Assessment and occurrence of various heavy metals in surface water of Ganga river around Kolkata: a study for toxicity and ecological impact. Environmental Monitoring and Assessment. 160, 207, 2010.

18. ADAMU C., NGANJE T., EDET A. Heavy metal contamination and health risk assessment associated with abandoned barite mines in Cross River State, southeastern Nigeria. Environmental Nanotechnology, Monitoring \& Management. 3, 10, 2014.

19. LOHANI M., SINGH A., RUPAINWAR D., DHAR D. Seasonal variations of heavy metal contamination in river Gomti of Lucknow city region. Environmental Monitoring and Assessment. 147, 253, 2008.

20. TURGEON O., BLANCHET R., GAGNE D., LAUZIERE J., VEZINA C., VAISSIERE E., AYOTTE P., DERY S. Exposure to toxic metals and persistent organic pollutants in Inuit children attending childcare centers in Nunavik, Canada. Environmental Science and Technology. 46, 4614, 2012.

21. MOLKA F., AMEL H. Cadmium as a possible cause of bladder cancer: a review of accumulated evidence. Environmental Science and Pollution Research. 21, 10561, 2014.

22. LIN Y., CAFFREY J., LIN J., BAYLISS D., FARAMAWI M., BATESON T., et al. Increased risk of cancer mortality associated with cadmium exposures in older Americans with low zinc intake. Journal of Toxicology and Environmental Health, Part A, 76, 2013.

23. PARK R., BENA J., STAYNER L., SMITH R., GIBB H., LEE P. Hexavalent chromium and lung cancer in the chromate industry: A quantitative risk assessment. Risk Analysis. 24, 1099, 2004.

24. CHEN H., TENG Y., LI J., WU J., WANG J. Source apportionment of trace metals in river sediments: A comparison of three methods. Environmental Pollution. 211, 28, 2016.

25. HE M, WANG Z., TANG H. The chemical, toxicological and ecological studies in assessing the heavy metal pollution in the Le'an River, China. Water Research. 32, 510, 1998.

26. TENG Y., NI S., WANG J., ZUO R., YANG J. A geochemical survey of trace elements in agricultural and non-agricultural topsoil in Dexing area, China. Journal of Geochemical Exploration. 104, 118, 2010.

27. YUAN G., LIU C., CHEN L., YANG Z. Inputting history of heavy metals into the inland lake recorded in sediment 
profiles: Poyang Lake in China. Journal of Hazardous Materials. 185, 336, 2011.

28. CHEN H., CHEN R., TENG Y., WU J. Contamination characteristics, ecological risk and source identification of trace metals in sediments of the Le'an River (China). Ecotoxicology and Environmental Safety. 125, 85, 2016.

29. YU Y., WANG H., LI Q., WANG B., YAN Z., DING A. Exposure Risk of Rural Residents to Copper in the Le'an River Basin, Jiangxi Province, China. Science of the Total Environment. 548-549, 402, 2016.

30. LIU G., TAO L., LIU X., HOU J., WANG A., LI R. Heavy metal speciation and pollution of agricultural soils along Jishui River in non-ferrous metal mine area in Jiangxi Province, China. Journal of Geochemical Exploration. 132, 156, 2013.

31. CNMN (Nonferrous metal net of China) (2014) Asia's largest open pit copper mine: Dexing copper mine http://www. cnmn.com.cn/ ShowNews1.aspx?id=294433. Accessed 2 September 2017.

32. HORTON R. An index number system for rating water quality. J.Water. Pollut. Control. Fed. 37, 1, 1965.

33. GIRI S., SINGH A. Assessment of surface water quality using heavy metal pollution index in Subarnarekha River, India. Water Quality Exposure and Health. 5, 173, 2014.

34. PRASAD B., BOSE J. Evaluation of the heavy metal pollution index for surface and spring water near a limestone mining area of the lower Himalayas. Environmental Geology. 41, 183, 2001.

35. TAMASI G., CINI, R. Heavy metals in drinking waters from Mount Amiata. Possible risks from arsenic for public health in the province of Siena. Science of the Total Environment. 327, 41, 2004.

36. CMH (Chinese Ministry of Health) (2007) Chinese State Standards (CSS) for drinking water quality (GB5749-2006).

37. CAERIO S., COSTA M., RAMOS T., FERNANDES F., SILVEIRA N., COIMBRA A., MEDERIOS G., PAINHO M. Assessing heavy metal contamination in sado Estuary sediment: an index analysis approach. Ecological Indicators, 5, 155, 2005.

38. USEPA Risk assessment guidance for superfund volume I: human health evaluation manual (part E, Supplemental Guidance for Dermal Risk Assessment) Final. EPA/540/R/99/005 OSWER 9285.7-02EP PB99-963312 July 2004, Office of Superfund Remediation and Technology Innovation; U.S. Environmental Protection Agency, Washington, DC 2004.

39. USEPA United States Environmental Protection Agency, Quantitative Uncertainty Analysis of Super Fund Residential Risk Path Way Models for Soil and Ground Water: White Paper. Office of Health and Environmental Assessment, Oak Ridge, TN, USA 1996.

40. VAROL M. Dissolved heavy metal concentrations of the Kralkız1, Dicle and Batman dam reservoirs in the Tigris River basin, Turkey. Chemosphere. 93 (6), 954, 2013.

41. GUO Q, MA K., YANG L., HE K. Testing a dynamic complex hypothesis in the analysis of land use impact on lake water quality. Water Resources Management. 24 (7),1313, 2010.

42. HUANG B., LI Z., HUANG J., GUO L., NIE X., ZHANG Y., ZENG G. Adsorption characteristics of $\mathrm{Cu}$ and $\mathrm{Zn}$ onto various size fractions of aggregates from red paddy soil. Journal of Hazardous Materials. 264 (2), 176, 2014

43. ZHANG H., JIANG Y., WANG M., WANG P., SHI G., DING M. Spatial characterization, risk assessment, and statistical source identification of the dissolved trace elements in the Ganjiang River - feeding tributary of the
Poyang Lake, China. Environmental Science and Pollution Research. 24, 2890, 2017.

44. GIRI S., SINGH A. Risk assessment, statistical source identification and seasonal fluctuation of dissolved metals in the Subarnarekha River, India. J. Hazard. Mate. 265, 305, 2014.

45. WHO Guidelines for drinking-water quality, recommendations incorporating $1^{\text {st }}$ and $2^{\text {nd }}$ Addenda, $13^{\text {th }}$ edn. World Health Organization, Geneva 2008.

46. PRASAD B., BOSE J.M. Evaluation of the heavy metal pollution index for surface and spring water near a limestone mining area of the lower Himalayas. Environ Geol 41, 183, 2001.

47. WU B., ZHAO D., JIA H., ZHANG Y., ZHANG X., CHENG S. Preliminary risk assessment of trace metal pollution in surface water from Yangtze River in Nanjing section, China. Bulletin of Environmental Contamination and Toxicology, 82, 405, 2009.

48. LIU Y., ZHENG B., FU Q., MENG W., WANG Y. Risk assessment and management of arsenic in source water in China. Journal of Hazardous Material, 170, 729, 2009.

49. KRISHNA A., MOHAN K. Risk assessment of heavy metals and their source distribution in waters of a contaminated industrial site. Environmental Science and Pollution Research. 21, 3653, 2014.

50. LU X., WANG L., LI L., LEI K., HUANG L., KANG D. Multivariate statistical analysis of heavy metals in street dust of Baoji, NW China. Journal of Hazardous Materials. 173, 744, 2010.

51. SAEEDI M., LI L., SALMANZADEH M. Heavy metals and polycyclic aromatic hydrocarbons: pollution and ecological risk assessment in street dust of Tehran. Journal of Hazardous Materials. 227, 9, 2012.

52. UNESCO (The United Nations Educational, Scientific and Cultural Organization). Ecological Effects of Heavy-metal Pollution in the Dexing Copper Mine Region (Jian Xi Province, China) (France) 1996.

53. LUO X., YU S., ZHU Y., LI X. Trace metal contamination in urban soils of China. Environmental Science \& Technology. 421, 17, 2012.

54. WILLIAM M., PETER R., STEFAN A. Heavy metal pollution in the Rhine basin. Environmental Science \& Technology. 27, 786, 1993.

55. Agency for Toxic Substances and Disease Registry (ATSDR). Toxicological Profile for Cadmium. Atlanta, GA: U.S. Department of Health and Human Services. Public Health Service. 2012

56. NEAL C., NEAL M., HILL, L., WICKHAM H. The water quality of the River Thames Basin of south/south-eastern England, Science of the Total Environment, 360, 254, 2006.

57. NRIAGU J. A history of global metal pollution. Science. 272, 223, 1990.

58. CHEN T., LIU X., ZHU M., ZHAO K., WU J., XU J., HUANG P. Identification of trace element sources and associated risk assessment in vegetable soils of the urban-rural transitional area of Hangzhou, China. Environmental Pollution. 151, 67, 2008.

59. LUO W., LU Y., ZHANG Y., FU W., WANG B., JIAO W., WANG G., TONG X., GIESY J. Watershed-scale assessment of arsenic and metal contamination in the surface soils surrounding Miyun Reservoir, Beijing, China. Journal of Environmental Management. 91, 2599, 2010.

60. MATTHIAS K., KATJA B., CHRISTINA S., VILEM P., MARTIN S., TOMAS D., JOSEF K., TOMAS V., MARTIN S. Impact of land use on water quality in the upper Nisa catchment in the Czech Republic and in Germany. Science of the Total Environment, 586, 1316, 2017. 
61. LUO L., MA Y., ZHANG S., WEI D., ZHU Y. An inventory of trace element inputs to agricultural soils in China. Journal of Environmental Management. 90, 2524, 2009.

62. LI S., XU Z., CHENG X., ZHANG Q. Dissolved trace elements and heavy metals in the Danjiangkou Reservoir. China, Environmental Geology. 55, 977, 2008.
63. LI J., HE M., HAN W., GU Y. Analysis and assessment on heavy metal sources in the coastal soils developed from alluvial deposits using multivariate statistical methods, Journal of Hazardous Materials. 164, 976, 2009.

\section{Supporting Information}

Table S1. Parameters of the heavy metal pollution index (HPI) in surface water.

\begin{tabular}{|c|c|c|c|}
\hline & $\begin{array}{c}\mathrm{S}_{\mathrm{i}}(\mathbf{C M C}) * \\
(\mu \mathrm{g} / \mathrm{L})\end{array}$ & $\begin{array}{c}\mathrm{I}_{\mathrm{i}}(\mathbf{C C C}) * \\
(\mu \mathrm{g} / \mathrm{L})\end{array}$ & $\begin{array}{c}\text { Unit weightage } \\
\left(\mathrm{W}_{\mathrm{i}}\right)\end{array}$ \\
\hline $\mathrm{Cr}$ & 16 & 11 & 0.0625 \\
\hline $\mathrm{Ni}$ & 470 & 52 & 0.0021 \\
\hline $\mathrm{Cu}$ & 13 & 9.0 & 0.0769 \\
\hline $\mathrm{Cd}$ & 2.0 & 0.25 & 0.5000 \\
\hline $\mathrm{Pb}$ & 65 & 2.5 & 0.0154 \\
\hline
\end{tabular}

$\mathrm{CMC}$, Criterion Maximum Concentration; CCC, Criterion Continuous Concentration

* USEPA (2006)

\section{References}

1. ZENG X., LIU Y., YOU S., ZENG G., TAN X., HU X., HU X., HUANG L., LI F. Spatial distribution, health risk assessment and statistical source identification of the trace elements in surface water from the Xiangjiang River, China. Environmental Science and Pollution Research. 22, 9400, 2015.

2. USEPA, Edition of the Drinking Water Standards and Health Advisories, U.S.Environmental Protection Agency, 2006.

3. USEPA Risk assessment guidance for superfund volume I: human health evaluation manual (part E, Supplemental Guidance for Dermal Risk Assessment) Final. EPA/540/R/99/005 OSWER 9285.7-02EP PB99-963312 July 2004, Office of Superfund Remediation and Technology Innovation; U.S. Environmental Protection Agency, Washington, DC, 2004.

4. IQBAQL J., SHAH M.H., AKHTER G. Characterization, source apportionment and health risk assessment of trace metals in freshwater Rawal Lake, Pakistan. Journal of Geochemical Exploration, 125, 94, 2013.

Table S2, Parameters and their sources relates to human health risk assessment.

\begin{tabular}{|c|c|c|c|c|}
\hline Parameter & Symbol & Units & Reference value & \multirow{2}{*}{ Source } \\
\hline Chemical concentration in water & $\mathrm{C}_{\mathrm{w}}$ & $\mu \mathrm{g} / \mathrm{L}$ & Site-specific & \\
\hline Body weight Adult & $\mathrm{B}_{\mathrm{w}} \mathrm{A}$ & $\mathrm{kg}$ & 65 & Zeng et al. 2015 \\
\hline Body weight Children & $\mathrm{B}_{\mathrm{w}} \mathrm{C}$ & $\mathrm{kg}$ & 22 & Zeng et al. 2015 \\
\hline Ingestion rate of water Adult & IR A & $\mathrm{L} \mathrm{day}^{-1}$ & 2.2 & Zeng et al. 2015 \\
\hline Ingestion rate of water Children & IR C & $\mathrm{L}_{\text {day }}{ }^{-1}$ & 1.5 & Zeng et al. 2015 \\
\hline Exposed skin surface area Adult & SA A & $\mathrm{m}^{2}$ & 1.80 & USEPA 2004 \\
\hline Exposed skin surface area Children & SA C & $\mathrm{m}^{2}$ & 0.66 & USEPA 2004 \\
\hline Exposed skin time & ET & $\mathrm{h}_{\text {day }^{-1}}$ & 0.58 & Iqbal et al. 2013 \\
\hline Exposure frequency & $\mathrm{EF}$ & day year ${ }^{-1}$ & 350 & USEPA 2004 \\
\hline Exposure duration Adult & ED A & year & 30 & Zeng et al. 2015 \\
\hline Exposure duration Children & ED C & year & 6 & Zeng et al. 2015 \\
\hline Permeability coefficient & $\mathrm{K}_{\mathrm{p}}$ & $\mathrm{cm} / \mathrm{h}$ & Chemical-specific & USEPA 2004 \\
\hline conversion factor & $\mathrm{CF}$ & - & 0.001 & USEPA 2004 \\
\hline Averaging time Adult & AT A & day & 10950 & \\
\hline Averaging time Children & AT C & day & 2190 & \\
\hline Average time (carcinogenic effects) & AT & day & 25550 & \\
\hline
\end{tabular}

